\title{
Treatment of wastewater generated from coke oven by adsorption on steelmaking slag and its effect on cementitious properties
}

\author{
Yogesh Nathuji Dhoble* and Sirajuddin Ahmed \\ Department of Civil Engineering, Jamia Millia Islamia (Central University), New Delhi 110 025, India
}

In this study, steelmaking slag is selected as an adsorption material to treat coke-oven wastewater. The study shows the use of solid waste to treat liquid waste of the same industry. The full effect of adsorption on steel slag with coke-oven wastewater has been analysed using SEM, XFR, XRD, FTIR and GC-MS. The adsorption pattern for steel slag at high temperatures, i.e. up to $1100^{\circ} \mathrm{C}$ was studied. It is observed that adsorption of pollutants does not favour higher temperature. Leaching studies showed increase in traces of heavy metals. However, only arsenic was found to be leaching beyond permissible limits. GC-MS studies showed no disorption of organic compounds from the treated slag. Compressive strength slightly weakened for the slag after adsorption, but lime saturation factor as well as soundness favoured the use of treated slag as an adsorbent. Overall analysis suggests that steel slag can be used for adsorption of coke-oven wastewater pollutant at lower temperatures. Thus steelmaking slag is found to be an efficient, readily available and economical adsorbent for removal of toxins from the coke-oven wastewater at lower temperatures.

Keywords: Coke-oven wastewater, compressive strength, leaching, steelmaking slag.

COKE-OVEN wastewater generated during quenching of the coke produced in the coke oven is highly toxic in nature due to the presence of phenols, ammonia, cyanides and several other PAH compounds ${ }^{1-3}$. Specially phenolics, heterocyclic compounds and PAH compounds present in the coking wastewater are mutative and carcinogenic ${ }^{4}$. Thus, the treatment of coke-oven wastewater is essential before it is discharged ${ }^{5}$. Several treatment processes are designed to meet the norms set by various governments for the discharge of effluents. The treatment of coke-oven wastewater is possible through two- or three-stage activated sludge process and the maximum removal efficiencies obtained are 90-99.9\% for chemical oxygen demand (COD), phenols, thiocyanate and $\mathrm{NH}_{4}^{+}-\mathrm{N}$ (refs 6, 7). In a study, anaerobic anoxic-oxic membrane bioreactor was

\footnotetext{
*For correspondence. (e-mail: yogeshdhoble@gmail.com)
}

operated for more than 500 days and the results obtained were found to be satisfactory ${ }^{8}$. Several other treatments like sequential batch reactor (SBR), two-step upflow anaerobic sludge blanket, ozonation and supercritical water oxidation have provided good results for the removal of toxic effluents ${ }^{9-11}$. Biochemical oxidation and dephenolization plants, popularly known as BOD plant, are used in the steel industry. Further, oxidation treatment processes like UV-photolysis and electro-oxidation are used for the removal of PAH compounds ${ }^{2}$.

Adsorption on steel slag is an endothermic and spontaneous process ${ }^{12-16}$. Most of the adsorption studies on the steel slag show that the adsorption data fit the Langmuir as well as Freundlich isotherms and adsorption kinetics fits the pseudo-second-order Lagergren equation. Adsorption studies have been conducted on coke-oven wastewater with one or two parameters. Studies show that $500 \mathrm{~g} \mathrm{l}^{-1}$ of Gonwana shale of India removes $74.11 \%$ phenol $^{17}$, $250 \mathrm{~g}^{-1}$ of coking coal removes COD and phenol at $58.08 \%$ and $67.12 \%$ respectively $^{18}$, and $200 \mathrm{~g} \mathrm{l}^{-1}$ of activated coke removes COD and colour of the effluent at $91.6 \%$ and $90 \%$ respectively ${ }^{19}$. Removal of phenol, ammonia and thiocyanate by steel slag using batch studies as well as column studies has been reported ${ }^{20-22}$. No study has reported the effect of adsorption of steel slag on coke-oven wastewater. Also, no studies are available on the adsorption in continuous mode of treatment in the steel industry ${ }^{23}$. Thus, finding an efficient method of treatment remains a challenge.

Several types of slag are generated at various stages in the iron and steel industry. Steelmaking slag is a waste material produced from the basic oxygen furnace during the production of steel. Slag contains iron ore, limestone, olivine, merwinite, $\mathrm{C}_{3} \mathrm{~S}, \mathrm{C}_{2} \mathrm{~S}, \mathrm{C}_{4} \mathrm{AF}, \mathrm{C}_{2} \mathrm{~F}$, RO phase (CaO-FeO-MnO-MgO solid solution) and free- $\mathrm{CaO}^{24}$. Air-cooled slag and water-quenched slag impart several different properties. Air-cooled slag forms lumps, whereas water-quenched slag gives granular and porous structure. This granular steelmaking slag is utilized to remove phosphorus ${ }^{25}, \mathrm{Cr}, \mathrm{Pd}, \mathrm{Cu}$ and $\mathrm{Zn}^{26}$. Removal of heavy metal ions from acid mine drainage has been reported ${ }^{27}$. Use of steelmaking slag and other alkaline products (limestone) helps increase the $\mathrm{pH}$ and causes high levels of alkalinity ${ }^{28}$. 
The present study examines the use of steel slag produced in the same industry as an adsorbent for the treatment of coke-oven wastewater. It shows the complex nature of coke-oven wastewater and the steel slag generated during steelmaking process. Steel slag was characterized by scanning electron microscope (SEM), energy dispersive X-ray spectroscopy (EDS) and X-ray diffraction (XRD). Coke-oven wastewater was characterized by gas chromatography-mass spectrometry (GC-MS) using analytical methods. Steel slag was treated under different temperature conditions for adsorption studies. The studies were performed by analysis of GC-MS and XRD data. Studies were conducted on the leaching of heavy metals from both treated and untreated slag under acidic and alkaline conditions, and results were obtained by inductively coupled plasma mass spectrometry (ICPMS). Cementitious properties like setting time and compressive strength were compared with treated and untreated slag under different percentage ratios of slag and cement.

\section{Materials and methods}

Steelmaking slag was collected from the slag dumping yard in Jamshedpur, Jharkhand, India. Slag was screened for different particle sizes, washed with distilled water and dried at $150^{\circ} \mathrm{C}$ for $24 \mathrm{~h}$ and then kept in a desiccator until further use. Coke-oven wastewater was obtained from the Bokaro Steel Plant in Jharkhand. Sieve analysis was done using mechanical shaker and with different sieves. Slag composition was measured using a spectrometer (WDXRF Spectrometer-Bruker S4 PIONEER). SEM images were obtained (Zeiss model: V5:05; SIGMA) and EDS was used for elemental analysis. XRD (Rigaku Smartlab Guidance $\mathrm{CuK} \alpha$ irradiation $1.54 \AA$, $40 \mathrm{kV}, 30 \mathrm{~mA}$ ) and FTIR (Vertex 70, Bruker from 400 to $4000 \mathrm{~cm}^{-1}$ ) were done. $\mathrm{KBr}$ pellets were made using 3 star Hydraulik press made by Morinda Hydraulik. ICPMS was used for leachate analysis (Agilent 7900). The BET surface area, pore diameter and pore volume were measured (Quantachrome NovaWin with nitrogen). Benzene was used as the solvent for making the organic phase of all the samples in the GC-MS studies. The benzene used was of AR-grade having sulphur compounds $\mathrm{CS}_{2} \quad 0.00003 \%$, thiophene $\mathrm{C}_{4} \mathrm{H}_{4} \mathrm{~S} \quad 0.0002 \%$, minimum assay (GC) $99.7 \%$ and refractive index 1.499-1.501. GC-MS studies were also done (GCMS-QP2010 Ultra instrument with Rxi-5Sil MS; length $=30 \mathrm{~m}$, I.D. $=$ $0.25 \mathrm{~mm}, \mathrm{~d} f=0.25 \mu \mathrm{m})$. Column was used with the following conditions: Inlet mode: split ratio: $10: 1$. Table 1 gives the settings used for column oven temperature.

The concentration of pollutant in coke-oven wastewater was very high and the wastewater used was undiluted. Steel slag $(100 \mathrm{~g})$ was poured into $200 \mathrm{ml}$ of wastewater so that sufficient adsorbent was available for the adsorption of pollutants in the wastewater. Amount of required slag was assessed based on previous studies ${ }^{17-19,29}$. The slag temperature was varied at $100^{\circ} \mathrm{C}, 750^{\circ} \mathrm{C}, 950^{\circ} \mathrm{C}$ and $1100^{\circ} \mathrm{C}$ to observe the effect of adsorption on steel slag. The experiment required precautions as blasts may occur at the time of contacting very hot slag with wastewater at room temperature. Usually, studies report the effect of temperature up to $50^{\circ} \mathrm{C}$. The elevated temperature up to $1100^{\circ} \mathrm{C}$ was used to check if the hot slag coming out of the furnace could be quenched with the coke-oven wastewater. This would reduce the water requirement for quenching of hot slag and coke-oven wastewater would get treated. The data obtained from GC-MS, XRD and FTIR were analysed.

Leaching studies were conducted before and after adsorption on a slag of $150 \mu \mathrm{m}$, which was air-dried and then exposed to acidic, neutral and alkaline conditions. The acidic conditions were maintained under $0.1 \mathrm{~N}$ acetic $\operatorname{acid}^{30}$ and alkaline conditions maintained using $0.1 \mathrm{~N}$ $\mathrm{NaOH}$. Under neutral conditions, only distilled water was used. A container with flat bottom surface of $150 \mathrm{~cm}^{2}$ was chosen so that distilled water was in continuous contact with the slag; no agitation was provided during leaching. Next, $25 \mathrm{~g}$ of slag with $250 \mathrm{ml}$ of distilled water (liquid/solid $=10$ ) was taken. The duration of leaching was maintained for 7, 30 and 50 days. The liquid was separated from the slag for leachate analysis. Heavy metals like $\mathrm{Bi}, \mathrm{Pd}, \mathrm{Cr}, \mathrm{Cu}, \mathrm{Ni}, \mathrm{Zn}, \mathrm{As}$ and $\mathrm{Fe}$ were analysed by ICP-MS and organic content by GC-MS studies ${ }^{31,32}$.

The change in cementitious properties before and after adsorption of the coke-oven wastewater onto the steel slag was checked by normal consistency, initial and final setting time, soundness and compressive strength. The parameters like activity modulus, lime saturation factor, silica modulus, hydraulic activity and alumina modulus were also monitored. Soundness was checked by

Table 1. Settings used for column oven temperature

\begin{tabular}{rcc}
\hline Rate & Temperature $\left({ }^{\circ} \mathrm{C}\right)$ & Hold time $(\min )$ \\
\hline 0 & 50 & 2 \\
5 & 250 & 2 \\
15 & 280 & 19 \\
\hline
\end{tabular}

\section{Box 1. Setting for GC-MS studies}

Control mode: Constant linear velocity $(40.5 \mathrm{~cm} / \mathrm{s})$; High pressure injection: $71.5 \mathrm{kPa}$; Purge flow rate: $3 \mathrm{ml} / \mathrm{min}$; Interface temperature: $270^{\circ} \mathrm{C}$; Ion source temperature: $230^{\circ} \mathrm{C}$; Solvent elution time: $5.50 \mathrm{~min}$; Data sampling time: 6-64.98 min; Measurement mode: Scan; Mass range: $\mathrm{m} / \mathrm{z} \quad 40-650$ and Event time: $0.20 \mathrm{~s}$ 


\section{RESEARCH ARTICLES}

Le-Chateliers apparatus. Compressive strength was measured with automatic compressive testing machine (AMIL Ltd) for which blocks of Mortar of the size of $70.6 \mathrm{~mm} \times$ $70.6 \mathrm{~mm} \times 70.6 \mathrm{~mm}$ were made. Normal consistency and change in the setting time were recorded using Vicat apparatus. Finer steel slag of the size less than $90 \mu \mathrm{m}$ was used for these studies. The slag was taken in a small tank and kept submerged for $1 \mathrm{~h}$ for completion of the adsorption process. Most studies suggest that adsorption is a spontaneous process. Three grades of sand, i.e. grades 1-3 are chosen in equal ratio while making the mortar blocks according to IS 650:1991. Cement-to-sand ratio was kept at $1: 3$. The blocks of the mortar with varying composition of steel slag and cement were made. Steel slag used for making the blocks was of two types. Slag which is not adsorbed and the slag which is adsorbed in coke oven wastewater. The slag to cement composition was varied in the range of $5: 20:: 95: 80$ weight percentage while making the blocks. Variation in the XRD pattern with $50 \%$ cement and $50 \%$ slag before and after adsorption was observed.

\section{Results and discussion}

\section{Characterization of materials}

Steelmaking slag: The steel slag was whitish and dusty and size of the grain varied from $0.75 \mu \mathrm{m}$ to $4 \mathrm{~mm}$ in diameter. Sieve analyses showed that steel slag was wellgraded. Table 2 shows the slag with $\mathrm{CaO}, \mathrm{Fe}_{2} \mathrm{O}_{3}$ and $\mathrm{SiO}_{2}$ as the main constituents. Figure 1 shows the porous nature of the steel slag, which indicates abundance of adsorption sites on its surface. Elements like O, Si, Ca, $\mathrm{Al}, \mathrm{Mg}, \mathrm{C}$ and $\mathrm{K}$ are found in the steel slag. XRD confirmed the presence of $\mathrm{Ca}(\mathrm{OH})_{2}, \mathrm{CaCO}_{3}, \mathrm{C}_{2} \mathrm{~S}$ and $\mathrm{C}_{3} \mathrm{~S}$ in the sample. FTIR showed $\mathrm{Si}-\mathrm{O}-\mathrm{Si}$ bend stretching. The surface morphology of steel slag particles showed abun- dance of sites, loosely bounded and porous. The BET surface area, pore diameter and pore volume were measured in the sample $\left(11.6 \mathrm{~m}^{2} / \mathrm{g}, 4.06 \mathrm{~nm}\right.$ and $0.010 \mathrm{cc} / \mathrm{g}$ respectively). According to IUPAC, the material can be classified as mesoporous. This is also confirmed by other researchers $^{33}$.

Coke-oven wastewater: Coke-oven wastewater is brown in colour with $\mathrm{pH}$ of 7.8 and chemical oxygen demand of $1047 \mathrm{mg} \mathrm{l}^{-1}$, phenol $247 \mathrm{mg} \mathrm{l}^{-1}$, ammonium nitrogen $460 \mathrm{mg} \mathrm{l}^{-1}$, thiocyanates $175 \mathrm{mg} \mathrm{l}^{-1}$, cyanide $47 \mathrm{mg} \mathrm{l}^{-1}$ and other complex organic compounds (Table 3). Suspended solids are also present in the wastewater and also

Table 2. Properties of slag and cement

\begin{tabular}{|c|c|c|c|}
\hline Sample & $\begin{array}{l}\text { Slag before } \\
\text { adsorption }\end{array}$ & $\begin{array}{l}\text { Slag after } \\
\text { adsorption }\end{array}$ & Cement \\
\hline $\mathrm{CaO}(\%)$ & 46.21 & 46.59 & 60.84 \\
\hline $\mathrm{Fe}_{2} \mathrm{O}_{3}(\%)$ & 14.89 & 16.96 & 3.2 \\
\hline $\mathrm{SiO}_{2}(\%)$ & 9.52 & 11.91 & 20.31 \\
\hline $\mathrm{MgO}(\%)$ & 2.51 & 1.83 & 3.17 \\
\hline $\mathrm{Al}_{2} \mathrm{O}_{3}(\%)$ & 1.94 & 2.21 & 5.24 \\
\hline $\mathrm{SO}_{3}(\%)$ & 0.25 & 0.21 & 1.12 \\
\hline $\mathrm{TiO}_{2}(\%)$ & 0.56 & 0.61 & - \\
\hline $\mathrm{MnO}(\%)$ & 0.52 & 0.48 & - \\
\hline $\mathrm{K}_{2} \mathrm{O}(\%)$ & 0.02 & 0.17 & - \\
\hline $\mathrm{Na}_{2} \mathrm{O}(\%)$ & 0.04 & 0.13 & - \\
\hline $\mathrm{Cu}(\mathrm{ppm})$ & 265.55 & 261.96 & - \\
\hline $\mathrm{Nb}(\mathrm{ppm})$ & 42.59 & 44.47 & - \\
\hline $\mathrm{S}(\mathrm{ppm})$ & 4835.20 & 5247.84 & - \\
\hline $\mathrm{Sr}(\mathrm{ppm})$ & 201.72 & 198.34 & - \\
\hline $\mathrm{V}(\mathrm{ppm})$ & 370.60 & 394.08 & - \\
\hline $\mathrm{Zr}(\mathrm{ppm})$ & 13.02 & 21.14 & - \\
\hline Activity modulus & 5.32 & 4.25 & 3.41 \\
\hline Hydraulic activity & 50.37 & 45.90 & 47.05 \\
\hline Alumina modulus & 0.13 & 0.13 & 1.64 \\
\hline Silica modulus & 0.57 & 0.62 & 2.41 \\
\hline Lime saturation factor & 1.22 & 1.01 & 0.93 \\
\hline $\mathrm{C}_{3} \mathrm{~S}$ & 80.73 & 59.45 & 50.35 \\
\hline
\end{tabular}

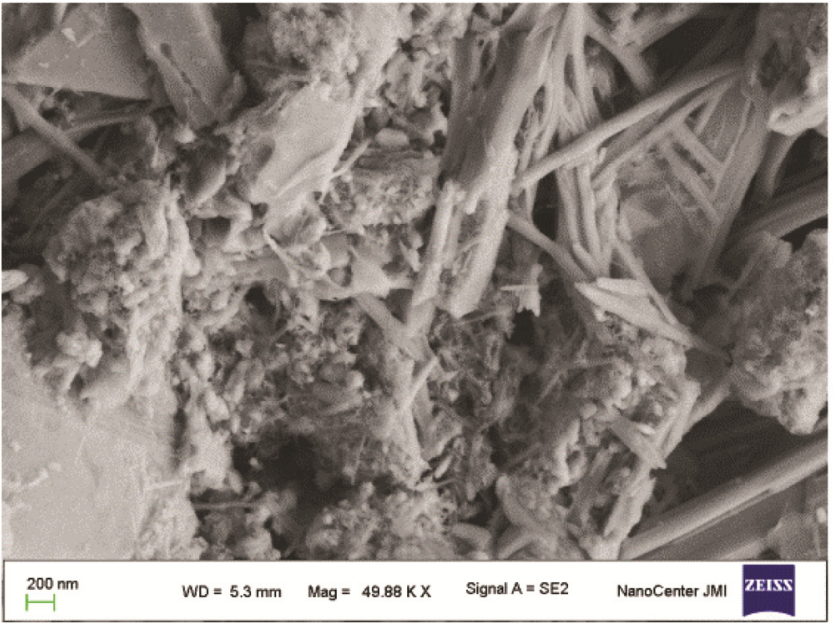

Figure 1. SEM of steel slag.
Table 3. Organic compounds in coke-oven wastewater

\begin{tabular}{cl}
\hline Retention time & \multicolumn{1}{c}{ Compounds } \\
\hline 8.579 & Phenol \\
10.621 & O-Cresol \\
11.310 & $m$-Cresol \\
15.932 & Benzo(b) pyridine \\
17.477 & Benzo(B) pyrrole \\
20.352 & Anthracene \\
25.270 & Heptadecane \\
27.520 & Eicosane \\
28.471 & $n$-Hexylpentadecane \\
29.695 & Eicosane \\
33.046 & Pentadecanoic acid \\
36.381 & Benzo(k) fluoranthene \\
36.768 & Octadecanoic acid \\
41.884 & Indeno(1,2,3-cd)pyrene \\
46.907 & Squalene \\
\hline
\end{tabular}




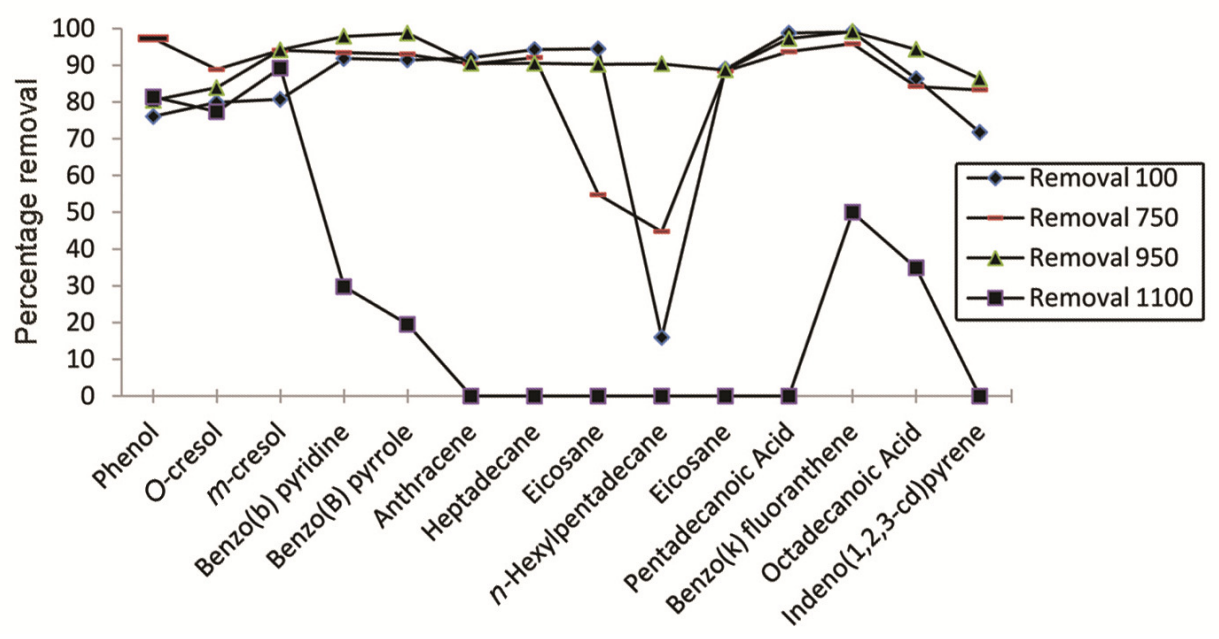

Figure 2. Percentage removal of organic compounds at different temperatures.

elements like C, O, Na, Mg, Al, Si, S, Cl, K, Ca, Mn, Fe and $\mathrm{Cu}^{34}$.

\section{Adsorption studies}

The first direct effect of treatment of slag by coke-oven wastewater is decolourization of the wastewater. This may be due to the presence of $\mathrm{Ca}$ and $\mathrm{Mg}$ oxides in the slag. GC-MS studies on the coke-oven wastewater before and after adsorption with steel slag at various temperature conditions showed $80 \%-99 \%$ removal of organic compounds by adsorption of steel slag. It was found that slag at a higher temperature of about $1100^{\circ} \mathrm{C}$ was not able to adsorb the organic pollutants; one of the reasons could be high turbulence during addition of high-temperature slag in the wastewater at $30^{\circ} \mathrm{C}$. It may be due to over activation of slag, which could not take the advantage of its activated sites caused by temperature gradients. Figure 2 shows the percentage removal of organic compounds at $100^{\circ} \mathrm{C}, 750^{\circ} \mathrm{C}, 950^{\circ} \mathrm{C}$ and $1100^{\circ} \mathrm{C}$. It shows that the removal of organic pollutants is satisfactory when the slag used for adsorption has temperature in the range 100 $950^{\circ} \mathrm{C}$, whereas further increase in temperature up to $1100^{\circ} \mathrm{C}$ could not remove benzo(b)pyridine, benzo(B)pyrrole, anthracene, heptadecane, eicosane, $n$-hexylpentadecane, pentadecanoic acid and indeno(1,2,3-cd)pyrene compounds. Thus adsorption of pollutants at higher temperatures is not favourable.

Figure 3 shows XRD of steel slag before and after adsorption at elevated temperature. The XRD pattern did not show many distinguished peaks indicating amorphous nature of the slag, which might be due to quenching of hot slag from the furnace ${ }^{35}$. XRD pattern shows $\mathrm{CaCO}_{3}$ peaks at 27 and 29 theta, $\mathrm{C}_{2} \mathrm{~S}, \mathrm{C}_{3} \mathrm{~S}$ and $\mathrm{C}_{4} \mathrm{AF}$ peaks from at 30 to 35 theta $^{36}$. The improved cementitious properties (increase in $\mathrm{C}_{2} \mathrm{~S}, \mathrm{C}_{3} \mathrm{~S}$ and $\mathrm{C}_{4} \mathrm{AF}$ ) are seen at higher temperatures. The XRD patterns of the steel slag at different temperatures after adsorption with coke-oven wastewater do not show any significant change when compared. However, Figure 4 shows that after quenching with wastewater, peaks in the XRD get reduced or diminished; this may be due to conversion of slag into amorphous state. The percentage removal of organic content at $1100^{\circ} \mathrm{C}$ is very less compared to percentage removal of organic content at $100^{\circ} \mathrm{C}, 750^{\circ} \mathrm{C}$ and $950^{\circ} \mathrm{C}$, as shown in Figures 2 and 3 . It can be concluded that $\mathrm{CaCO}_{3}, \mathrm{C}_{2} \mathrm{~S}$, $\mathrm{C}_{3} \mathrm{~S}$ and $\mathrm{C}_{4} \mathrm{AF}$ may not be participating in the process of adsorption and the change in XRD pattern is due to increase in glassy content in the slag ${ }^{37}$.

FTIR studies showed functional groups participating in the process of adsorption. This was done by observing shifts in the functional groups ${ }^{38}$. FTIR studies were done before and after adsorption of the slag on wastewater. $\mathrm{KBr}$ pellets of the slag sample were made for analysis to reduce the signal-to-noise ratio. However, no change in the results was observed without the use of KBr. Figure 5 shows the results of FTIR analysis. The strong and broad band ranging from $2900 \mathrm{~cm}^{-1}$ to $3600 \mathrm{~cm}^{-1}$ belongs to -OH stretching vibrations, $1400 \mathrm{~cm}^{-1}$ to $1500 \mathrm{~cm}^{-1}$ bands belong to amorphous $\mathrm{CaCO}_{3}$, and peaks between $400 \mathrm{~cm}^{-1}$ and $800 \mathrm{~cm}^{-1}$ belong to bending vibration of the surface $\mathrm{Si}-\mathrm{O}-\mathrm{Si}$ and $\mathrm{MgO}, \mathrm{MnO}^{39,40}$. The peaks of $\mathrm{Si}-\mathrm{O}$ and $\mathrm{Al}-\mathrm{O}$ stretching are found between $910.4 \mathrm{~cm}^{-1}$ and $971 \mathrm{~cm}^{-1}$ (ref. 41). Calcite exist at around $874 \mathrm{~cm}^{-1}$ (ref. 31). The vibrational changes of high intensity are observed at $405 \mathrm{~cm}^{-1}$ to $900 \mathrm{~cm}^{-1}$, which shows participation of calcite and $\mathrm{Si}-\mathrm{O}-\mathrm{Si}$ in the adsorption process. Effect of temperature variation is more observable in this zone. Medium intensity changes are observed at 900-1500 $\mathrm{cm}^{-1}$, which shows that $\mathrm{SO}_{3}$ and $\mathrm{CaCO}_{3}$ participate in the process of adsorption. The XRD of treated slag at different temperatures did not show the $\mathrm{CaCO}_{3}$ peak, this also confirms that $\mathrm{CaCO}_{3}$ takes part in the adsorption process. 


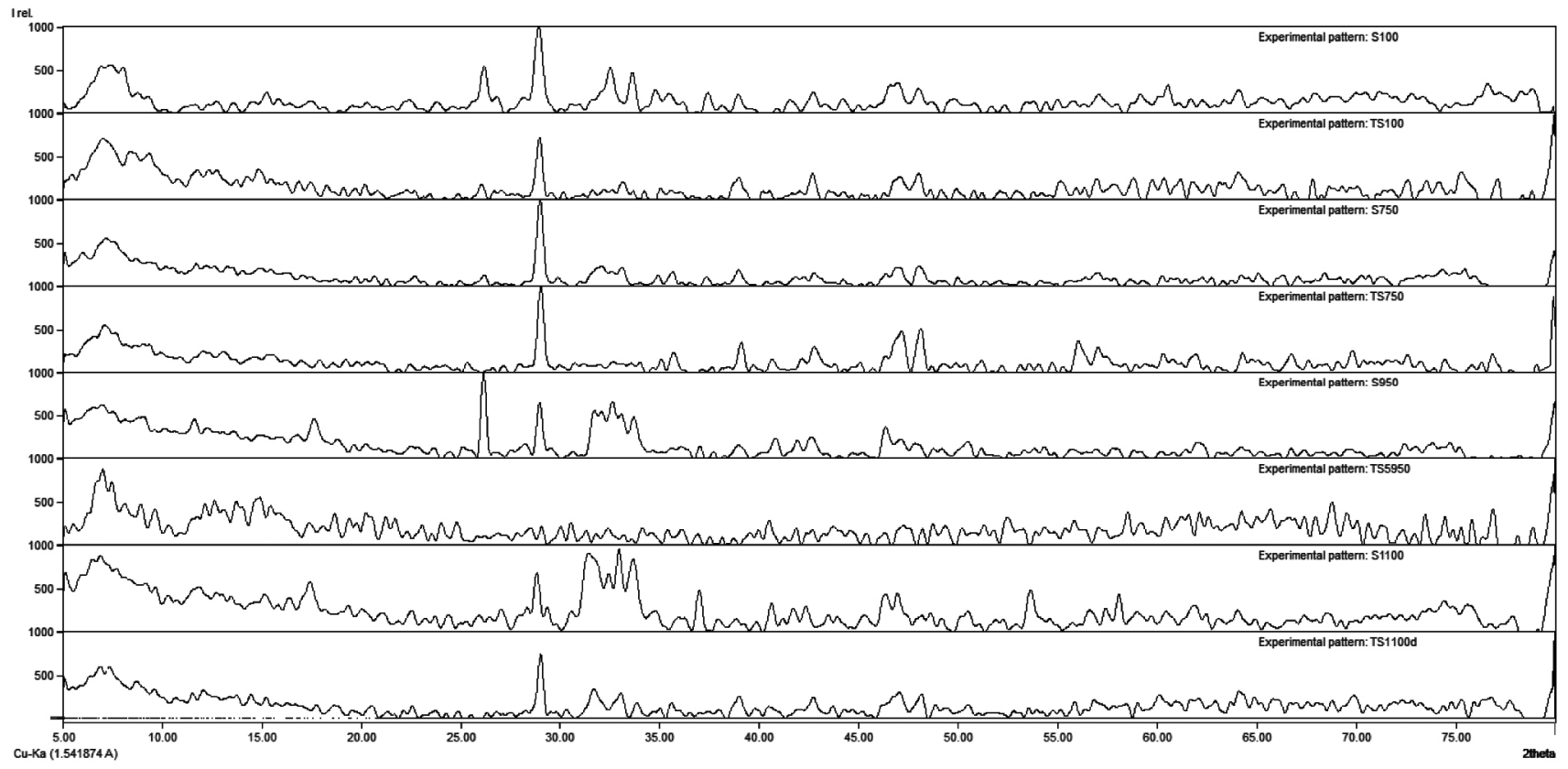

Figure 3. XRD of slag before and after adsorption.
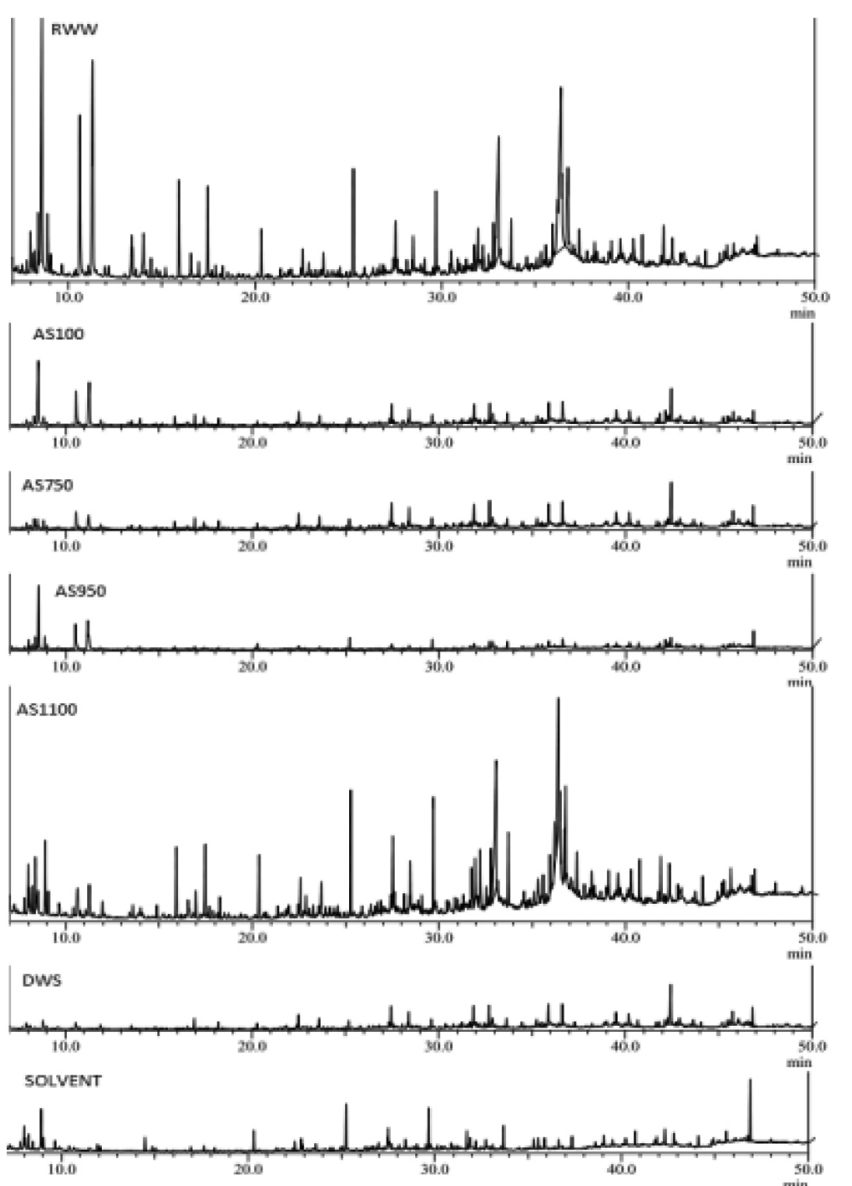

Figure 4. GC-MS of wastewater under different conditions. RWW, Real coke-oven wastewater; AS100, AS750, AS950 and AS1100 are the samples of the wastewater treated with steel slag at $100^{\circ} \mathrm{C}, 750^{\circ} \mathrm{C}$, $950^{\circ} \mathrm{C}$ and $1100^{\circ} \mathrm{C}$ respectively; DWS, distilled water with solvent.
Figure 4 reveals reduction in $\mathrm{MnO}, \mathrm{SO}_{3}$ and $\mathrm{MgO}$ in the slag after adsorption. Thus it can be concluded that $\mathrm{CaCO}_{3}, \mathrm{MgO}, \mathrm{MnO}, \mathrm{SO}_{3}$ and silica participate in the process of adsorption.

\section{Leaching studies}

Studies done elsewhere showed that leaching of heavy metals from the slag is intermittent, but can last for many years $^{42}$. Calcite precipitation would stop only 50-80 years after slag disposal ${ }^{43}$. Leaching of heavy metals from the steel slag had negative impact on the environment. Toxicity characteristic leaching procedure, batch leaching test and column leaching test were used in most of the previously reported work. No accepted protocol is available for the leaching test on the steel $\operatorname{slag}^{44}$. Some studies suggest liquid to solid ratio of 10-30 for steel slag with leaching time of 30-47 days ${ }^{45,46}$. Rapidly cooled steel slag helps reduce the leaching of $\mathrm{Ca}, \mathrm{Fe}, \mathrm{Al}, \mathrm{Cr}, \mathrm{Mo}$, whereas leaching of $\mathrm{V}$ and $\mathrm{Si}$ could not be reduced ${ }^{47}$.

Figure 6 reveals that $\mathrm{Fe}$, As and $\mathrm{Zn}$ are prominent metals leaching under alkaline conditions ${ }^{48}$. Pd and $\mathrm{Bi}$ leached less from the adsorbed slag. Leaching was not observed for $\mathrm{Zn}$ and As under acidic and neutral conditions, but was found under alkaline conditions. $\mathrm{Pd}$ and $\mathrm{Bi}$ also did not leach under neutral conditions, but did so under acidic and alkaline conditions. $\mathrm{Ni}, \mathrm{Pd}$ and $\mathrm{Bi}$ leached more under acidic conditions. The concentration of $\mathrm{Cr}$ did not exceed the permissible limits $\left(\mathrm{Cr}<0.05 \mathrm{mg} \mathrm{l}^{-1}\right)$ of the Indian standards (second revision IS 10500) for the 50 days leaching test. Leaching of $\mathrm{Ni}$ and $\mathrm{Fe}$ was also found within the permissible limits $\left(\mathrm{Ni}<0.02 \mathrm{mg} \mathrm{l}^{-1}\right.$ and $\mathrm{Fe}<$ 

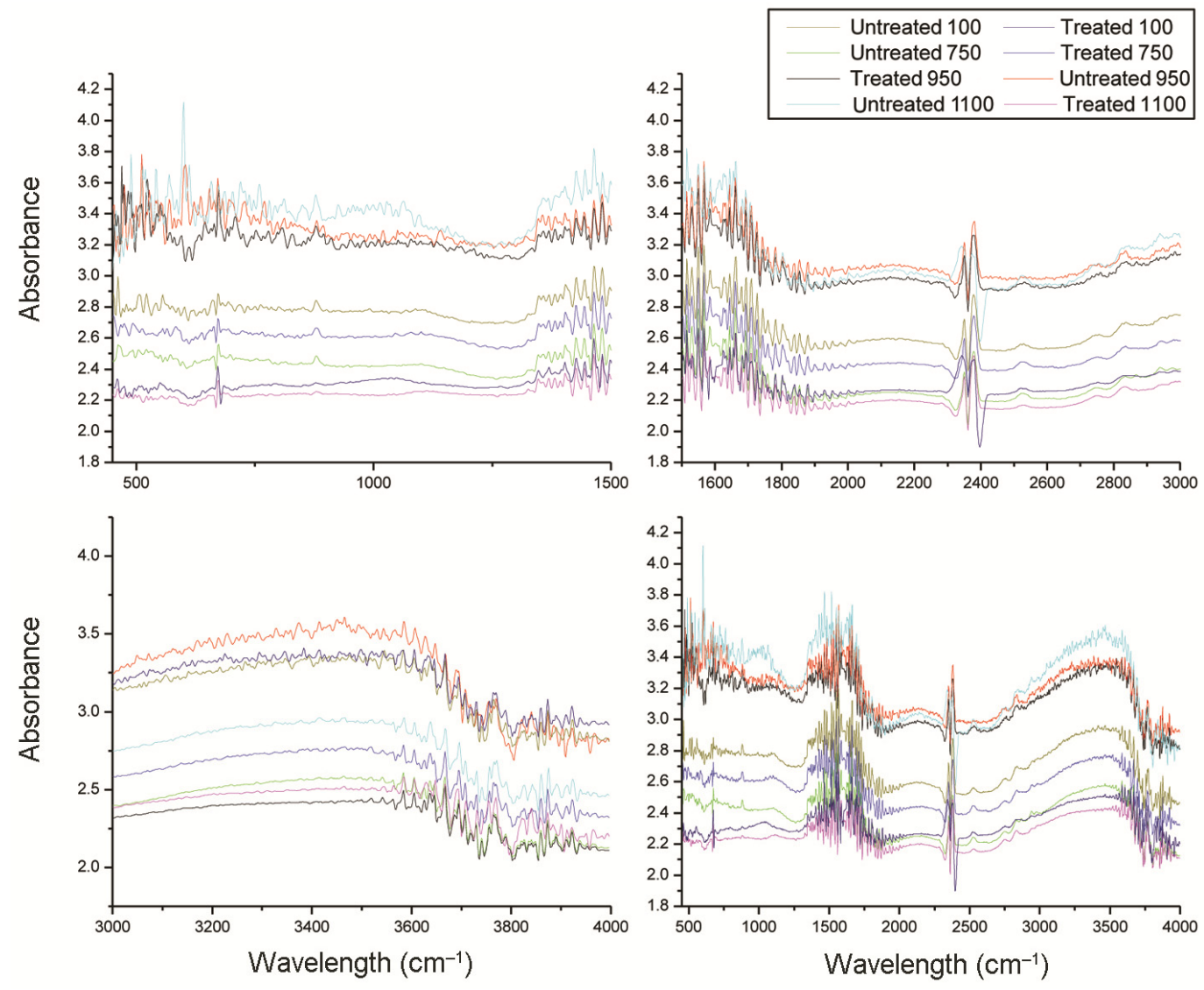

Figure 5. FTIR of slag before and after adsorption.

Table 4. Composition of mortar and its properties

\begin{tabular}{|c|c|c|c|c|c|c|c|c|c|}
\hline Ingredients of mortar and its properties & CSBA20 & CSAA20 & CSBA15 & CSAA15 & CSBA10 & CSAA 10 & CSBA5 & CSAA5 & $\mathrm{C} 100$ \\
\hline Cement (gm) & 160 & 160 & 170 & 170 & 180 & 180 & 190 & 190 & 200 \\
\hline Slag (before adsorption; g) & 40 & - & 30 & - & 20 & - & 10 & - & \\
\hline Slag (after adsorption; $\mathrm{m}$ ) & - & 40 & - & 30 & - & 20 & - & 10 & - \\
\hline Sand of grade $1-3$ in equal proportion $(\mathrm{g})$ & 600 & 600 & 600 & 600 & 600 & 600 & 600 & 600 & 600 \\
\hline Water requirement $(\%)$ & 36.21 & 36.73 & 36.63 & 36.51 & 36.90 & 37.20 & 37.7 & 37.73 & 38.34 \\
\hline Initial setting time (min) & 100 & 100 & 50 & 50 & 45 & 45 & 45 & 40 & 30 \\
\hline Soundness $(\mathrm{mm})$ & 11 & 9 & 10 & 9 & 8 & 6 & 8 & 6 & 8 \\
\hline
\end{tabular}

CSBA20, Mortar composition with 20\% untreated slag; CSAA20, Mortar composition with 20\% treated slag; CSBA15, Mortar composition with 15\% untreated slag; CSAA15, Mortar composition with 15\% treated slag; CSBA10, Mortar composition with $10 \%$ untreated slag; CSAA10, Mortar composition with $10 \%$ treated slag; CSBA5, Mortar composition with 5\% untreated slag; CSAA5, Mortar composition with 5\% untreated slag; C100, Mortar composition with no slag.

$0.3 \mathrm{mg} \mathrm{l}^{-1}$ ) under acidic and alkaline conditions. Leaching of $\mathrm{Zn}$ and $\mathrm{Cu}$ was also found to be under permissible limits $\left(\mathrm{Zn}<5 \mathrm{mg} \mathrm{l}^{-1}\right.$ and $\left.\mathrm{Cu}<0.05 \mathrm{mg} \mathrm{l}^{-1}\right)$. However, leaching of As exceeded beyond permissible limits $\left(\text { As }<0.05 \mathrm{mg} \mathrm{l}^{-1}\right)^{49}$. Overall it can be stated that steelmaking slag is non-toxic even after the process of adsorption. Figure 7 shows no significant change in organic content even after 50 days of leaching under acidic and alkaline conditions. The observable peaks in the filtrate are those of the solvent used.

\section{Cementitious properties}

The composition of steel slag may vary from place to place and process conditions of the furnace. Steel slag is known to have cementitious properties due to the presence of $\beta-\mathrm{C}_{2} \mathrm{~S}, \mathrm{C}_{3} \mathrm{~S}, \mathrm{C}_{4} \mathrm{AF}$ and $\mathrm{C}_{2} \mathrm{~F}$. Cementitious properties increase with its basicity ${ }^{50}$. Due to the presence of free lime, the use of steel slag is limited. Properly aged steel slag would not show expansion ${ }^{51}$. Use of alkali activators like $\mathrm{Na}_{2} \mathrm{SiO}_{3}$ increases the cementitious property 

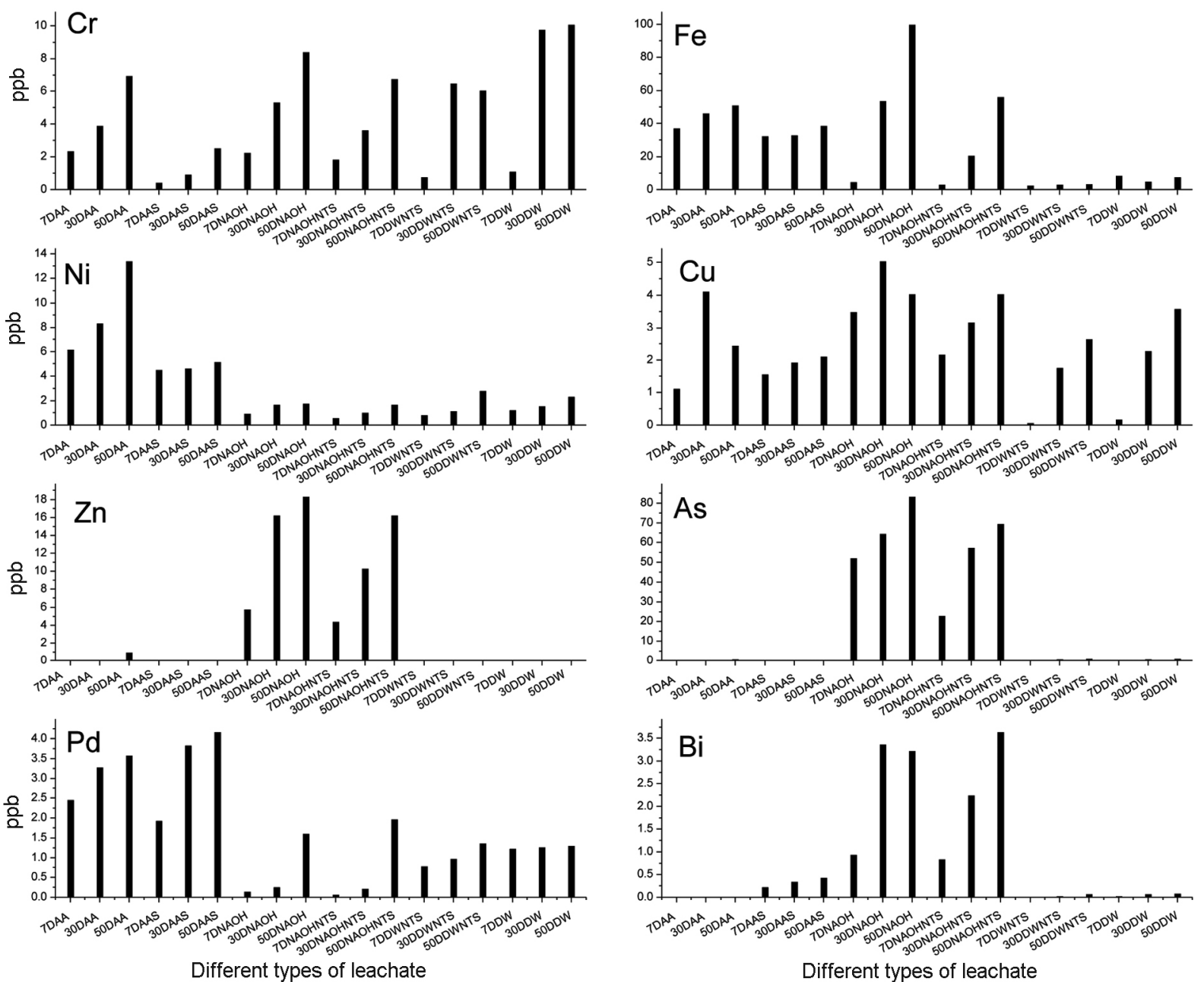

Figure 6. Leaching of heavy metals before and after adsorption. 7 DAA, 30 DAA and 50 DAA - 7 days, 30 days and 50 days acidic condition with slag after adsorption; 7 DAAS, 30 DAAS and 50 DAAS - 7 days, 30 days and 50 days acidic condition with slag before adsorption; 7 DNAOH, $30 \mathrm{DNAOH}$ and $50 \mathrm{DNAOH}-7$ days, 30 days and 50 days alkaline condition with slag after adsorption; 7 DNAOHNTS, 30 DNAOHNTS and 50 DNAOHNTS -7 days, 30 days and 50 days alkaline condition with slag before adsorption; 7 DDW, 30 DDW and 50 DDW -7 days, 30 days and 50 days neutral condition with slag before adsorption; 7 DDWNTS, 30 DDWNTS and 50 DDWNTS - 7 days, 30 days and 50 days neutral condition with slag after adsorption.

of the steel $\operatorname{slag}^{50}$. Studies indicate that super-fine steel slag has higher compressive strength for the first 100 days and it decreases after 100 days compared to ordinary steel slag $^{52}$. Studies indicate that steel slag can be converted to amorphous material by rapid quenching, which enhances the hydration properties of steel slag ${ }^{47}$.

Figure 8 shows the XRD pattern cement. The sample was prepared with cement to slag ratio as $1: 1$ and mixed with water to form a paste which was allowed to dry under atmospheric conditions. The dried sample was powdered after $24 \mathrm{~h}$ and XRD was performed. XRD with cement and unadsorbed slag showed better peaks than that of the sample with cement and treated slag with coke oven wastewater. This also confirms that cement when blended with treated slag at the ratio of $1: 1$ loses its cementitious properties. $\mathrm{C}_{3} \mathrm{~S}$ phase was found to be weak in the original slag, but cement had well-developed $\mathrm{C}_{3} \mathrm{~S}$ phase. When cement was mixed with treated slag, $\mathrm{C}_{3} \mathrm{~S}$ content was found to be improved. $\mathrm{C}_{3} \mathrm{~S}$ is the primary strength contributing phase. $\mathrm{Ca}(\mathrm{OH})_{2}$ was produced by hydration of calcium silicate phase. The main hydration products were $\mathrm{C}-\mathrm{S}-\mathrm{H}, \mathrm{Ca}(\mathrm{OH})_{2}$, ettringite, $\mathrm{C}_{3} \mathrm{~S}$ and $\mathrm{C}_{2} \mathrm{~S}$. $\mathrm{FeO}\left(41.725^{\circ}, 35.927^{\circ}\right.$ and $\left.60.482^{\circ}\right)$ in the slag was transformed into $\mathrm{FeO}(\mathrm{OH})$ in the strong alkali phase of hydrated cement phase. Shorter peak of $\mathrm{Ca}(\mathrm{OH})_{2}$ in the treated slag shows it had not gone into hydration phase equally.

Table 4 shows changes in the properties of mortar as the percentage of slag is changed. Box 2 shows the equations used for cementitious properties based on XRF results. Activity modulus for slag as well as cement was found to be good $(Z>1.6)$; however, the slag after its adsorption with coke-oven wastewater was slightly reduced. The same was true for hydraulic activity (excellent $i>16$ ) as well as for lime saturation factor (LSF) $)^{53}$. Reduced LSF in slag after adsorption showed that the free 

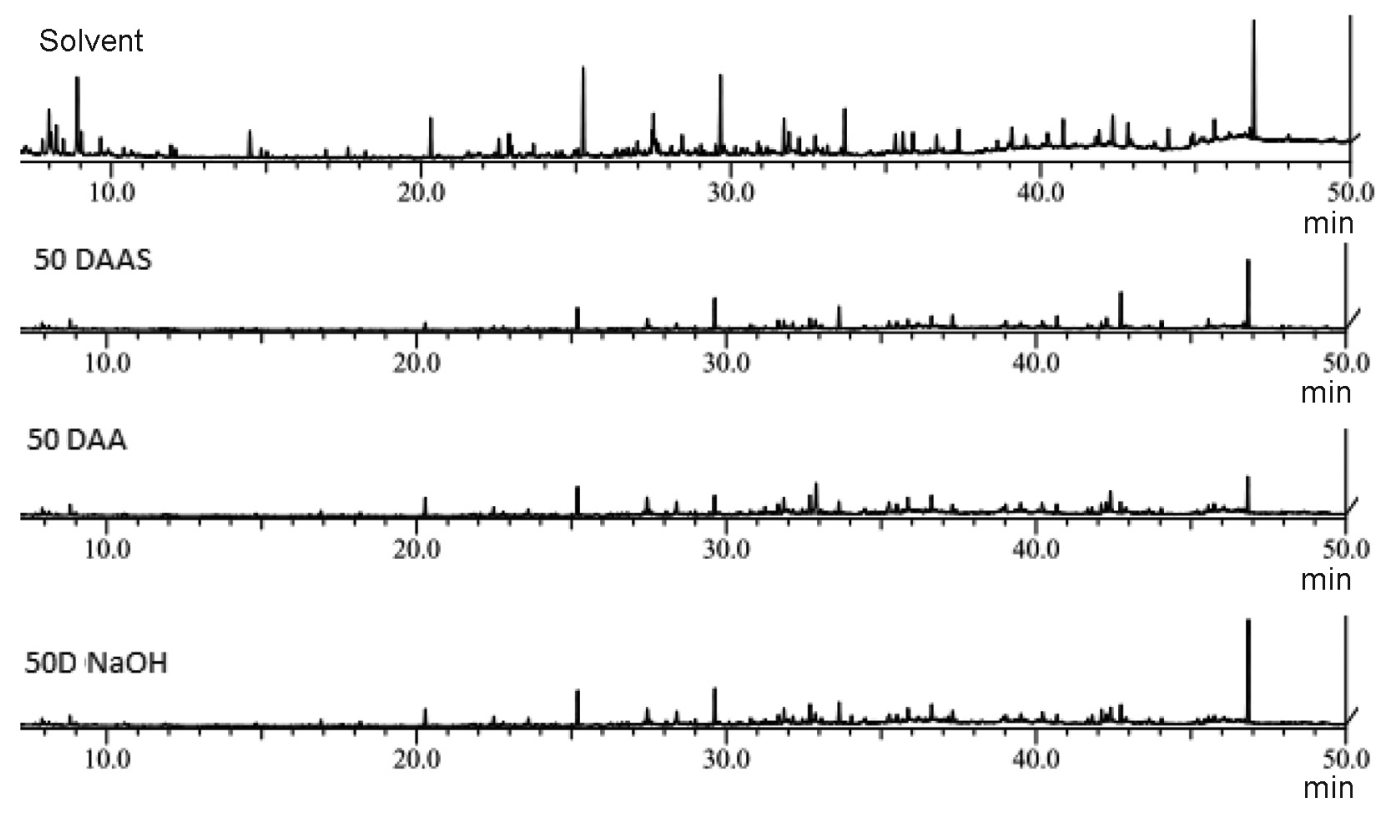

Figure 7. GC-MS of the leaching studies.

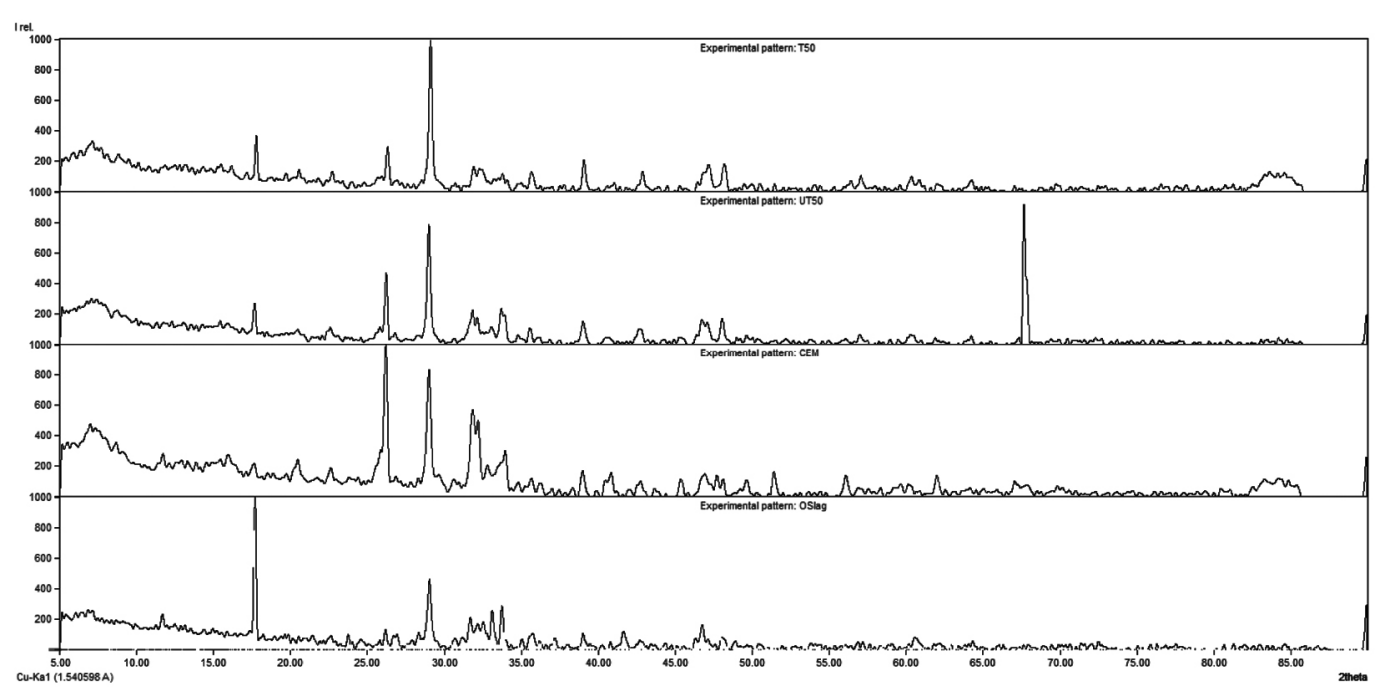

Figure 8. XRD of slag and cement under different compositions.

\begin{tabular}{|ll|}
\hline \multicolumn{3}{|c|}{ Box 2. Equations used to analyse cementious properties } \\
\hline Activity modulus $(\mathrm{Z})=\left(\mathrm{CaO}+\mathrm{MgO}+\mathrm{Al}_{2} \mathrm{O}_{3}\right) /\left(\mathrm{SiO}_{2}\right)($ ref. 53), & (1) \\
Hydraulic activity $(\mathrm{i})=20+\mathrm{CaO}+\mathrm{Al}_{2} \mathrm{O}_{3}+0.5 \mathrm{MgO}-2 \mathrm{SiO}_{2}($ ref. 53), & $(2)$ \\
Aluminia modulus $(\mathrm{AM})=\mathrm{Al}_{2} \mathrm{O}_{3} / \mathrm{Fe}_{2} \mathrm{O}_{3}$, & $(3)$ \\
Silica modulus $(\mathrm{SM})=\mathrm{SiO}_{2} /\left(\mathrm{Al}_{2} \mathrm{O}_{3}+\mathrm{Fe}_{2} \mathrm{O}_{3}\right)$, & $(4)$ \\
$\mathrm{Lime}$ saturation factor $(\mathrm{LSF})=\mathrm{CaO} /\left(2.8 \mathrm{SiO}_{2}+1.2 \mathrm{Al}_{2} \mathrm{O}_{3}+0.6 \mathrm{Fe}_{2} \mathrm{O}_{3}\right)$, & $(5)$ \\
$\mathrm{C}_{3} \mathrm{~S}=4.071 \mathrm{CaO}-7.6 \mathrm{SiO}_{2}+6.718 \mathrm{Al}_{2} \mathrm{O}_{3}+1.43 \mathrm{Fe}_{2} \mathrm{O}_{3}+2.852 \mathrm{SO}_{3}$. & (6) \\
\hline
\end{tabular}

lime in the slag had reduced. It was also observed that silica modulus (SM) increased in the slag after adsorption; however, SM of slag is less than cement. Aluminia modulus showed that the slag was low in aluminate and ferrite phases. $\mathrm{C}_{3} \mathrm{~S}$ content in the slag after adsorption was found to be reduced. Figure 9 shows that compressive strength of the slag after treatment has reduced and that 5-10\% replacement of cement with the slag either before or after adsorption provides sufficient strength after 90 days of curing time, conforming to Indian Standards IS:8112 for ordinary portland cement and IS:456 for portland slag cement $^{36}$. 


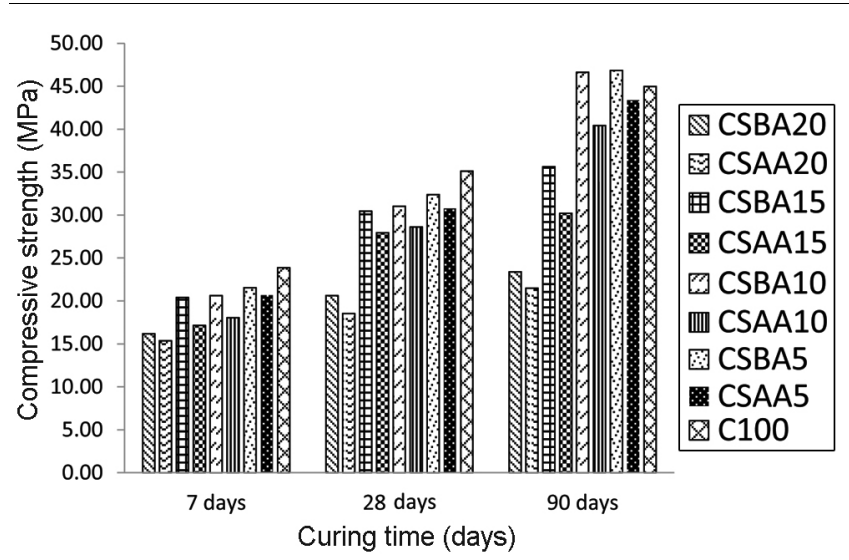

Figure 9. Compressive strength of steel slag before and after adsorption.

\section{Conclusion}

The adsorption of steel slag on coke-oven wastewater is studied. It is found that the steel slag removes most of the organic pollutants from the wastewater up to a temperature of $950^{\circ} \mathrm{C}$. Thereafter, the effect of turbulence caused by temperature does not favour the adsorption process. $\mathrm{XRD}, \mathrm{XRF}$ and FTIR studies conclude that the slag actively participates in the adsorption process. Also, $\mathrm{CaCO}_{3}, \mathrm{MnO}, \mathrm{MgO}, \mathrm{SO}_{3}$ and silica are found to participate in the process of adsorption. The study suggests that hot steel slag can be quenched by coke-oven wastewater. However, on an industrial scale, its feasibility would require further studies.

The leaching studies show all metals under consideration leach within the permissible limits for both treated and untreated slag, except arsenic. GC-MS studies do not show any disorption of organics from the adsorbed slag; thus favouring the process of adsorption of pollutants from the coke-oven wastewater.

Studies to check the effect of adsorption of coke-oven wastewater on cementitious properties show that the adsorbed slag provides slightly less compressive strength compared to unadsorbed slag. Overall, it can be concluded that there is no adverse effect on the cementitious properties. Hence, the steelmaking slag can be used for the treatment of coke-oven wastewater.

1. Ghose, M., Complete physico-chemical treatment for coke plant effluents. Water Res., 2002, 36, 1127-1134; doi:10.1016/S00431354(01)00328-1.

2. Biswas, J., Evaluation of various methods and efficiencies for treatment of effluent from iron and steel industry - a review. Int. J. Mech. Eng. Robot Res., 2013; http://www.ijmerr.com/ uploadfile/2015/0409/20150409043210915.pdf (accessed on 29 August 2017).

3. Papadimitriou, C. A., Samaras, P. and Sakellaropoulos, G. P., Comparative study of phenol and cyanide containing wastewater in CSTR and SBR activated sludge reactors. Bioresour. Technol., 2009, 100, 31-37; doi:10.1016/j.biortech.2008.06.004.

4. Dong, Y. and Zhang, J., Testing the genotoxicity of coking wastewater using Vicia faba and Hordeum vulgare bioassays. Eco- toxicol. Environ. Saf., 2010, 73, 944-948; doi:10.1016/ j.ecoenv.2009.12.026.

5. Ahmed, S., Chandra, U. and Rathi, R., Waste water treatment technologies commonly practiced in major steel industries of India. In 16th Annual International Sustainable Development Research Conference, The University of Hong Kong, Hong Kong, 2010.

6. Vázquez, I., Rodríguez, J., Marañón, E., Castrillón, L. and Fernández, Y., Study of the aerobic biodegradation of coke wastewater in a two and three-step activated sludge process. $J$. Hazard. Mater., 2006, 137, 1681-1688; doi:10.1016/j.jhazmat. 2006.05.007.

7. Marañón, E., Vázquez, I., Rodríguez, J., Castrillón, L. and Fernández, Y., Coke wastewater treatment by a three-step activated sludge system. Water Air Soil Pollut., 2008, 192, 155164; doi:10.1007/s11270-008-9642-y.

8. Zhao, W., Huang, X. and Lee, D., Enhanced treatment of coke plant wastewater using an anaerobic-anoxic-oxic membrane bioreactor system. Sep. Purif. Technol., 2009, 66, 279-286; doi:10.1016/j.seppur.2008.12.028.

9. Marañón, E., Vázquez, I., Rodríguez, J., Castrillón, L., Fernández, Y. and López, H., Treatment of coke wastewater in a sequential batch reactor (SBR) at pilot plant scale. Bioresour. Technol., 2008, 99, 4192-4198; doi:10.1016/j.biortech.2007.08.081.

10. Wang, W., Han, H., Yuan, M., Li, H., Fang, F. and Wang, K., Treatment of coal gasification wastewater by a two-continuous UASB system with step-feed for COD and phenols removal. Bioresour. Technol., 2011, 102, 5454-5460; doi:10.1016/ j.biortech.2010.10.019.

11. Chang, E.-E., Hsing, H.-J., Chiang, P.-C., Chen, M.-Y. and Shyng, J.-Y., The chemical and biological characteristics of coke-oven wastewater by ozonation. J. Hazard. Mater., 2008, 156, 560-567; doi:10.1016/j.jhazmat.2007.12.106.

12. Li, X. L., Liu, X. and Cao, G. P., Kinetic and thermodynamic studies of adsorption of phosphate on steel-slag filter material. Appl. Mech. Mater., 2014, 507, 707-710; doi:10.4028/ www.scientific.net/AMM.507.707.

13. Duan, J., Fang, H., Lin, J., Lin, J. and Huang, Z., Simultaneous removal of $\mathrm{NH}_{4}$ and $\mathrm{PO}_{4}^{3-}$ at low concentrations from aqueous solution by modified converter slag. Water Environ. Res., 2013, 85, 530-538; doi:10.2175/106143013X13596524516860.

14. Heksavalentnega, A. et al., Adsorption of hexavalent chromium from an aqueous solution of steel-making slag; http://mit.imt.si/ Revija/izvodi/mit145/strkalj.pdf (accessed on 4 September 2017).

15. Duan, J. and Su, B., Removal characteristics of Cd(II) from acidic aqueous solution by modified steel-making slag. Chem. Eng. J., 2014, 246, 160-167; doi:10.1016/j.cej.2014.02.056.

16. Lan, Y., Zhang, S., Wang, J. and Smith, R., Phosphorus removal using steel slag. Acta Metall. Sin. (Eng. Lett.), 2006, 19, 449-454; doi:10.1016/S1006-7191(06)62086-3.

17. Sadhu, K., Mukherjee, A., Shukla, S. K., Adhikari, K. and Dutta, S., Adsorptive removal of phenol from coke-oven wastewater using Gondwana shale, India: experiment, modeling and optimization. Desalin. Water Treat., 2014, 52, 6492-6504; doi:10.1080/19443994.2013.815581.

18. Gao, L., Li, S., Wang, Y. and Sun, H., Organic pollution removal from coke plant wastewater using coking coal. Water Sci. Technol., 2015, 72, 158; doi:10.2166/wst.2015.197.

19. He Zhang, M., Lin Zhao, Q., Bai, X. and Ye, Z. F., Adsorption of organic pollutants from coking wastewater by activated coke. Colloids Surf. A Phys. Eng. Asp., 2010, 362, 140-146; doi:10.1016/j.colsurfa.2010.04.007.

20. Dhoble, Y. N. and Ahmed, S., Equilibrium, kinetic and thermodynamic studies on the adsorption of thiocyanate by steel slag in an aqueous system. AET, 2017, 3; 193-203; doi:10.22104/ AET.2018.2670.1133.

21. Dhoble, Y. N. and Ahmed, S., Removal of phenol, ammonia and thiocyanate either alone or in combination by the adsorption with 
steel slag. Int. J. Eng. Res. Dev., 2017, 13, 2278-67; http://www. ijerd.com/paper/vol13-issue12/Version-1/L131217786.pdf (accessed on 18 January 2018).

22. Dhoble, Y. N. and Ahmed, S., Column studies for the simultaneous removal of phenol, ammonia and thiocyanate by the adsorption with steel slag. Int. J. Res. Appl. Sci. Eng. Technol., 2018, 2321-9653; www.ijraset.com (accessed on 19 April 2018).

23. Pal, P. and Kumar, R., Treatment of coke wastewater: a critical review for developing sustainable management strategies. Sep. Purif. Rev., 2014, 43, 89-123; doi:10.1080/15422119.2012. 717161.

24. Hooton, R., Shi, C. and Day, R., Selectivity of alkaline activators for the activation of slags. Cem. Concr. Aggr., 1996, 18, 8; doi:10.1520/CCA10306J.

25. Baker, M. J., David, W., Blowes and Ptacek, C. J., Laboratory development of permeable reactive mixtures for the removal of phosphorus from onsite wastewater disposal systems. Environ. Sci. Technol., 1998, 32, 2308-2316; doi:10.1021/ES970934W.

26. Liu, S.-Y., Gao, J., Qu, B. and Yang, Y., Adsorption behaviors of heavy metal ions by steel slag - an industrial solidwaste. In The Third International Conference on Bioinformatics and Biomedical Engineering, Beijing, China, 2009, pp. 1-4; doi:10.1109/ ICBBE.2009.5162282.

27. Feng, D., Van Deventer, J. S. J. and Aldrich, C., Removal of pollutants from acid mine wastewater using metallurgical byproduct slags. Sep. Purif. Technol., 2004, 40, 61-67; doi:10.1016/ j.seppur.2004.01.003.

28. Simmons, J. S. and Ziemkiewicz, P., An alternative alkaline addition for direct treatment of acid mine drainage, Mining and the environment, Sudbury, Canada, 2003.

29. Singh, G. and Prasad, B., Removal of ammonia from coke-plant wastewater by using synthetic zeolite. Water Environ. Res., 1997, 69, 157-161; doi:10.2307/25044857.

30. Lim, T.-T. and Chu, J., Assessment of the use of spent copper slag for land reclamation. Waste Manage. Res., 2006, 24, 67-73; doi: $10.1177 / 0734242$ X06061769.

31. Oh, C., Rhee, S., Oh, M. and Park, J., Removal characteristics of As(III) and As(V) from acidic aqueous solution by steel making slag. J. Hazard Mater., 2012, 213, 147-155; doi:10.1016/j. jhazmat.2012.01.074.

32. Ziemkiewicz, P., Steel slag: application for AMD control. In Conference on Hazardous Waste Research, 1998, pp. 44-62.

33. Navarro, C., Díaz, M. and Villa-García, M. A., Physico-chemical characterization of steel slag. Study of its behaviour under simulated environmental conditions. Environ. Sci. Technol., 2010, 44, 5383-5388; doi:10.1021/es100690b.

34. Pueyo, N., Rodríguez-Chueca, J., Ovelleiro, J. L. and Ormad, M. P., Limitations of the removal of cyanide from coking wastewater by treatment with hydrogen peroxide. Water, Air, Soil Pollut., 2016, 227, 222; doi:10.1007/s11270-016-2915-y.

35. Vicak, J., Tomkova, V., Ovcacikova, H., Ovcacik, F., Topinkova, M. and Matejka, V., Slag and Steel Production: Properties and Their Utilization, Metalurgija, Centar za informiranje željezare Sisak, vol. 52, 2013.

36. Kourounis, S., Tsivilis, S., Tsakiridis, P. E. E., Papadimitriou, G. D. D. and Tsibouki, Z., Properties and hydration of blended cements with steelmaking slag. Cem. Concr. Res., 2007, 37, 815822; doi:10.1016/j.cemconres.2007.03.008.

37. Karthikeyan, G. and Ilango, S. S., Adsorption of $\mathrm{Cr}(\mathrm{VI})$ onto activated carbons prepared from indigenous materials. E-J. Chem., 2008, 5, 666-678; doi:10.1155/2008/109398.

38. Beh, C. L., Chuah, T. G., Nourouzi, M. N. and Choong, T., Removal of heavy metals from steel making waste water by using electric arc furnace slag. E-J. Chem., 2012, 9, 2557-2564; doi: $10.1155 / 2012 / 128275$.

39. Ullah, R. and Dutta, J., Photocatalytic degradation of organic dyes with manganese-doped $\mathrm{ZnO}$ nanoparticles. J. Hazard. Mater., 2008, 156, 194-200; doi:10.1016/J.JHAZMAT.2007.12.033.

40. Jung, E.-J., Kim, W., Sohn, I. and Min, D.-J., A study on the interfacial tension between solid iron and $\mathrm{CaO}-\mathrm{SiO}_{2}-\mathrm{MO}$ system. J. Mater. Sci., 2010, 45, 2023-2029; doi:10.1007/s10853-0093946-1.

41. Chand, S., Paul, B. and Kumar, M., A comparative study of physicochemical and mineralogical properties of LD slag from some selected steel plants in India. J. Environ. Sci. Technol., 2016, 9, 75-87; doi:10.3923/jest.2016.75.87.

42. Gomes, J. F. P., Pinto, C. G. and Pinto, C. G., Leaching of heavy metals from steelmaking slags. Revista de Metallurgia, 2006, 42, 409-416; doi:10.3989/revmetalm.2006.v42.i6.39.

43. Riley, A. L. and Mayes, W. M., Long-term evolution of highly alkaline steel slag drainage waters. Environ. Monit. Assess., 2015, 187, 463; doi:10.1007/s10661-015-4693-1.

44. Tiwari, M. K., Bajpai, S., Dewangan, U. K. and Tamrakar, R. K., Suitability of leaching test methods for fly ash and slag: a review. J. Radiat. Res. Appl. Sci., 2015, 8, 523-537; doi:10.1016/ j.jrras.2015.06.003.

45. Chaurand, P. et al., Environmental impacts of steel slag reused in road construction: a crystallographic and molecular (XANES) approach. J. Hazard. Mater., 2006, 139, 537-542; doi:10.1016/j. jhazmat.2006.02.060.

46. De Windt, L., Chaurand, P. and Rose, J., Kinetics of steel slag leaching: batch tests and modeling. Waste Manag., 2011, 31, 225235; doi:10.1016/j.wasman.2010.05.018.

47. Tossavainen, M., Engstrom, F., Yang, Q., Menad, N., Lidstrom, Larsson M. and Bjorkman, B., Characteristics of steel slag under different cooling conditions. Waste Manage., 2007, 27, 13351344; doi:10.1016/j.wasman.2006.08.002.

48. Fjällborg, B., Li, B., Nilsson, E. and Dave, G., Toxicity identification evaluation of five metals performed with two organisms (Daphnia magna and Lactuca sativa). Arch. Environ. Contam Toxicol., 2006, 50, 196-204; doi:10.1007/s00244-0057017-6.

49. BIS, Indian Standard (Second Revision) IS 10500 (2012), Bureau of Indian Standard, New Delhi; 2012, pp. 1-16; http://cgwb.gov. in/Documents/WQ-standards.pdf

50. Shi, C., Characteristics and cementitious properties of ladle slag fines from steel production. Cem. Concr. Res., 2002, 32, 459-462; doi:10.1016/S0008-8846(01)00707-4.

51. Fronek, B., Bosela, P. and Delatte, N., Steel slag aggregate used in portland cement concrete. Transp. Res. Rec. J. Transp. Res. Board., 2012, 2267, 37-42; doi:10.3141/2267-04.

52. Wang, Q., Yang, J. and Yan, P., Cementitious properties of superfine steel slag. Powder Technol., 2013, 245, 35-39; doi:10.1016/ j.powtec.2013.04.016.

53. Kurdowski, W., Cement and Concrete Chemistry, Springer Science and Business, 2014, 9789400779, pp. 1-100.

ACKNOWLEDGEMENTS. We thank the Department of Nanotechnology, Jamia Millia Islamia, New Delhi and Advanced Instrumentation Research Facility, Jawaharlal Nehru University, New Delhi for providing instrumentation support for analysis of the sample.

Received 11 January 2018; revised accepted 1 January 2019

doi: $10.18520 / \mathrm{cs} / \mathrm{v} 116 / \mathrm{i} 8 / 1346-1355$ 